\title{
Essential amino acids to treat sarcopenia in patients with COPD?
}

\author{
E.P.A. Rutten, M.A. Spruit
}

Monaldi Arch Chest Dis 2010; 73: 1, $2-4$.

Program Development Centre, Ciro, a centre of expertise for chronic organ failure, Horn, the Netherlands.

Correspondence: Dr. Erica P.A. Rutten, Program Development Centre, Ciro, a centre of expertise for chronic organ failure, Hornerheide 1, 6085 NM, Horn, The Netherlands; e-mail: ericarutten@ciro-horn.nl

A shift in body composition from fat-free mass (FFM, a reflection of skeletal muscle mass) to fat mass (FM) is called sarcopenia and seems to be a physiological process of aging [1]. As COPD is predominantly present in elderly people, one would expect a comparable shift in body composition in these patients. However the decrease of FFM can be accelerated in patients with COPD [2]. Indeed, the prevalence of FFM depletion is about $30 \%$ in patients with moderate to severe COPD [3].

An abnormal loss of FFM may have a significant impact on the functional status in patients with COPD: a poor exercise performance [4], lower-limb muscle weakness [5] and an impaired disease-specific health status [6]. Moreover, various studies have shown that the FFM index (e.g., FFM in kilograms) divided by squared height (in meters, FFMI) is an independent predictor for survival, irrespective of fat mass, sex, smoking, lung function, and body mass index (e.g., body weight in kilograms) divided by squared height (in meters, BMI) $[7,8]$. Also, measurement of the midthigh cross-sectional area with computed tomography scan gives a better prediction of survival than BMI, irrespective of the pulmonary function impairment [9]. So, it seems essential to understand the pathogenesis of muscle wasting in patients with COPD, and in turn, possible therapeutic options.

\section{Pathogenesis of skeletal muscle wasting in COPD}

Why is the loss of skeletal muscle mass accelerated in patients with COPD? To start, COPD patients have a clear loss in daily physical activities compared to age-matched healthy peers [10]. Moreover, the excessive loss of skeletal muscle mass in patients with COPD differs somewhat from loss of FFM due to physical inactivity alone [11]. The development of skeletal muscle wasting in COPD is a consequence of a form of myopathy that involves a whole cascade of metabolic modifications directly or indirectly related to the underlying disease, like fibre type redistribution, effect of hypoxia, systemic inflammation and/or malnutrition $[12,13]$.
Skeletal muscle wasting is always the result of an imbalance between muscle protein synthesis and breakdown. An increased whole body protein breakdown and synthesis has been found in normal weight patients with COPD [14]. Moreover, myofibrillar protein breakdown was increased in COPD patients with a decreased BMI and a decreased FFMI compared to normal weight patients and healthy peers [15-17].

Besides protein metabolism, amino acid metabolism is more extensively investigated in COPD patients with an abnormal loss of FFM. Indeed, plasma branched-chain amino acid (BCAA) concentrations (the predominant part of the essential amino acids), particularly leucine, were lower in muscle-wasted compared to non-muscle wasted COPD patients [18-20]. In addition, plasma levels of BCAA positively correlates with FFM in patients with COPD [15]. Also, skeletal muscle glutamate concentration was decreased in normal weight patients with COPD compared to healthy peers [21] and plasma glutamate concentration was positively associated with FFM [15]. These results are in line with the review of a disturbed skeletal muscle glutamate metabolism in patients with COPD [22]. As BCAA and glutamate are the predominant anaplerotic amino acids, a decreased BCAA and glutamate concentration in cachectic COPD patients could imply alterations in the substrate metabolism [23].

\section{Management of muscle wasting in COPD}

Exercise-based rehabilitation has been shown to improve FFM in patients with and without baseline loss of FFM [24, 25]. Particularly resistance training of the muscles of ambulation has resulted in improvements in FFM, muscle strength, functional exercise performance and health status [26, 27]. Moreover, neuromuscular electrical stimulation of the lower-limb muscle seems also beneficial in malnourished COPD patients [28, 29].

Muscle protein synthesis is stimulated in the recovery period after resistance exercise [30]. However, the rate of muscle protein breakdown is also increased, thereby blunting the change in the net balance between synthesis and breakdown. Although 
net muscle protein balance is generally improved after resistance exercise, it remains negative. Therefore, nutrient intake is necessary to achieve positive net muscle protein balance. Indeed, ingestion of a relatively small amount of essential amino acids can effectively stimulate net muscle protein balance after resistance exercise in healthy subjects [31].

Del Negro et al. [32] report in the current issue of the Monaldi Archives for Chest Disease the effects of a 12-week amino acid supplementation in patients with GOLD stage 3 or 4 and an abnormal low FFM at baseline. FFM increased with a mean of 4 kilograms in the patients receiving the essential amino acid supplementation, without any change in the placebo group. These results suggest that supplementation of specific amino acids can also be a therapeutic option to stimulate protein synthesis in patients with COPD. Interestingly, physical activity also improved in the patients of the experimental group. This may also have contributed to the observed increases in FFM. Indeed, a combination of resistance training and nutritional interventions may be a promising candidate in fighting sarcopenia in patients with COPD.

\section{References}

1. Beaufrere B, Morio B. Fat and protein redistribution with aging: metabolic considerations. Eur J Clin Nutr 2000; 54 Suppl 3: S48-53.

2. Schols AMWJ, Soeters PB, Dingemans AMC, Mostert R, Frantzen PJ, Wouters EFM. Prevalence and characteristics of nutritional depletion in patients with stable COPD eligible for pulmonary rehabilitation. Am Rev Respir Dis 1993; 147: 1151-6.

3. Vermeeren MA, Creutzberg EC, Schols AM, et al. Prevalence of nutritional depletion in a large out-patient population of patients with COPD. Respir Med 2006; 100: 1349-55.

4. Baarends EM, Schols AM, Mostert R, Wouters EF. Peak exercise response in relation to tissue depletion in patients with chronic obstructive pulmonary disease. Eur Respir J 1997; 10: 2807-13.

5. Seymour JM, Spruit MA, Hopkinson NS, et al. The prevalence of quadriceps weakness in COPD and the relationship with disease severity. Eur Respir J 2009 Nov 6 [Epub ahead of print].

6. Mostert R, Goris A, Weling-Scheepers C, Wouters EF, Schols AM. Tissue depletion and health related quality of life in patients with chronic obstructive pulmonary disease. Respir Med 2000; 94: 859-67.

7. Schols AM, Broekhuizen R, Weling-Scheepers CA, Wouters EF. Body composition and mortality in chronic obstructive pulmonary disease. Am J Clin Nutr 2005; 82: 53-9.

8. Vestbo J, Prescott E, Almdal T, et al. Body mass, fatfree body mass, and prognosis in patients with chronic obstructive pulmonary disease from a random population sample: findings from the Copenhagen City Heart Study. Am J Respir Crit Care Med 2006; 173: 79-83.

9. Marquis K, Debigare R, Lacasse Y, et al. Midthigh muscle cross-sectional area is a better predictor of mortality than body mass index in patients with chronic obstructive pulmonary disease. Am J Respir Crit Care Med 2002; 166: 809-13.

10. Pitta F, Troosters T, Spruit MA, Probst VS, Decramer M, Gosselink R. Characteristics of physical activities in daily life in chronic obstructive pulmonary disease. $A m$ J Respir Crit Care Med 2005; 171: 972-7.
11. Franssen FM, Wouters EF, Schols AM. The contribution of starvation, deconditioning and ageing to the observed alterations in peripheral skeletal muscle in chronic organ diseases. Clin Nutr 2002; 21: 1-14.

12. Debigare R, Cote CH, Maltais F. Peripheral muscle wasting in chronic obstructive pulmonary disease. Clinical relevance and mechanisms. Am J Respir Crit Care Med 2001; 164: 1712-7.

13. Schols AM. Nutritional and metabolic modulation in chronic obstructive pulmonary disease management. Eur Respir J 2003; 46 Suppl: 81s-86s.

14. Engelen MP, Deutz NE, Wouters EF, Schols AM. Enhanced levels of whole-body protein turnover in patients with chronic obstructive pulmonary disease. Am J Respir Crit Care Med 2000; 162 (4 Pt 1): 1488-92.

15. Rutten EP, Franssen FM, Engelen MP, Wouters EF, Deutz NE, Schols AM. Greater whole-body myofibrillar protein breakdown in cachectic patients with chronic obstructive pulmonary disease. Am J Clin Nutr 2006; 83: 829-34.

16. Bolton CE, Broekhuizen R, Ionescu AA, et al. Cellular protein breakdown and systemic inflammation are unaffected by pulmonary rehabilitation in COPD. Thorax 2007; 62: 109-14

17. Broekhuizen R, Grimble RF, Howell WM, et al. Pulmonary cachexia, systemic inflammatory profile, and the interleukin 1beta -511 single nucleotide polymorphism. Am J Clin Nutr 2005; 82: 1059-64.

18. Hofford JM, Milakofsky L, Vogel WH, Sacher RS, Savage GJ, Pell S. The nutritional status in advanced emphysema associated with chronic bronchitis. A study of amino acid and catecholamine levels. Am Rev Respir Dis 1990; 141: 902-8.

19. Morrison WL, Gibson JNA, Scrimgeour C, Rennie MJ. Muscle wasting in emphysema. Clin Sci 1988; 75: 415-20.

20. Schols AMWJ, Deutz NEP, Mostert R, Wouters EFM. Plasma amino acid levels in patients with chronic obstructive pulmonary disease. Monaldi Arch Chest Med 1993; 48: 546-8.

21. Engelen MP, Wouters EF, Deutz NE, Menheere PP, Schols AM. Factors contributing to alterations in skeletal muscle and plasma amino acid profiles in patients with chronic obstructive pulmonary disease. Am J Clin Nutr 2000; 72: 1480-7.

22. Rutten EP, Engelen MP, Schols AM, Deutz NE. Skeletal muscle glutamate metabolism in health and disease: state of the art. Curr Opin Clin Nutr Metab Care 2005; 8: 41-51.

23. Bowtell JL, Marwood S, Bruce M, Constantin-Teodosiu D, Greenhaff PL. Tricarboxylic acid cycle intermediate pool size: functional importance for oxidative metabolism in exercising human skeletal muscle. Sports Med 2007; 37: 1071-88.

24. Franssen FM, Broekhuizen R, Janssen PP, Wouters EF, Schols AM. Effects of whole-body exercise training on body composition and functional capacity in normalweight patients with COPD. Chest 2004; 125: 2021-8.

25. Spruit MA, Wouters EF. New modalities of pulmonary rehabilitation in patients with chronic obstructive pulmonary disease. Sports Med 2007; 37: 501-18.

26. Bernard S, Whittom F, Leblanc P, et al. Aerobic and strength training in patients with chronic obstructive pulmonary disease. Am J Respir Crit Care Med 1999; 159: 896-901.

27. Spruit MA, Gosselink R, Troosters T, De Paepe K, Decramer M. Resistance versus endurance training in patients with COPD and peripheral muscle weakness. Eur Respir J 2002; 19: 1072-8.

28. Sillen MJ, Speksnijder CM, Eterman RM, et al. Effects of neuromuscular electrical stimulation of muscles of ambulation in patients with chronic heart failure or COPD: a systematic review of the English-language literature. Chest 2009; 136: 44-61. 
29. Vivodtzev I, Pepin JL, Vottero G, et al. Improvement in quadriceps strength and dyspnea in daily tasks after 1 month of electrical stimulation in severely deconditioned and malnourished COPD. Chest 2006; 129: 1540-8.

30. Biolo G, Maggi SP, Williams BD, Tipton KD, Wolfe RR. Increased rates of muscle protein turnover and amino acid transport after resistance exercise in humans. Am J Physiol 1995; 268: E514-20.
31. Borsheim E, Tipton KD, Wolf SE, Wolfe RR. Essential amino acids and muscle protein recovery from resistance exercise. Am J Physiol Endocrinol Metab 2002; 283: E648-57.

32. Dal Negro RW, Aquilani R, Bertacco S, Boschi F, Micheletto C, Tognella S. Comprehensive effects of supplemented essential amino acids (EAAs) in patients with severe chronic obstructive pulmonary disease and sarcopenia. Monaldi Arch Chest Dis 2010; 73: 25-33.

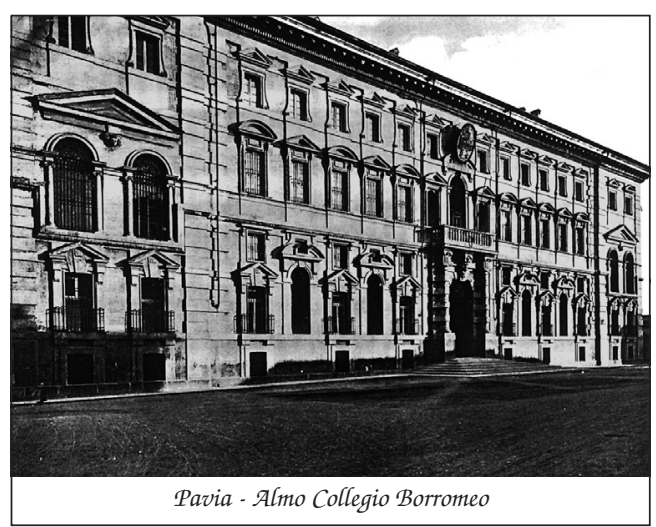

